\title{
INOVATIVNE TEHNOLOGIJE U VOZILU U FUNKCIJI SIGURNOSTI PJEŠAČKOG PROMETA ${ }^{3}$
}

\begin{abstract}
SAŽETAK
Ugroženost pješaka očituje se činjenicom kako upravo oni zauzimaju drugo mjesto po smrtnosti u prometu. U nastojanju da se brojke smrtnosti na cestama smanje, intervenirale su nacionalne vlasti i Europska komisija svojim programima i mjerama zaštite i sigurnosti u prometu. Njima je, osim infrastrukture i samog čovjeka (vozača), obuhvaćena i automobilska industrija od koje se također očekuje doprinos u smislu većeg stupnja sigurnosti prometa pa tako i njenih sudionika. Sukladno tome, danas smo svjedoci raznih automobilskih inovacija kojima je fokus pješak, zajedno sa svim okolnostima u kojima on može biti ugrožen u prometu. Nalet vozila na pješaka jedna je od najčešćih prometnih nesreća koja u većini slučajeva rezultira smrtonosnim ishodom. U nastojanju da se prometne nesreće s pješacima smanje, brojne automobilske tvrtke pokrenule su izradu aktivnih i pasiunih sustava koji će uvelike pomoći pravovremenom reagiranju vozača ili smanjiti težinu ozljeda kod pješaka uslijed naleta. Aktivni sustavi temelje se uglavnom na nekoj vrsti radarske tehnologije čiji je zadatak prepoznati pješaka koji se nalazi u zoni naleta vozila te vozača na vrijeme o tome obavijestiti ili preuzeti kontrolu nad brzinom i putanjom vozila i izbjeći udar. Pasivni sustavi nastoje smanjiti posljedice primarnog $i$ sekundarnog udara pješaka u vozilo, odnosno o tlo.
\end{abstract}

Ključne riječi: zaštita pješaka, sustavi sigurnosti u vozilu, sigurnost prometa

\section{UVOD}

Prometne nesreće u kojima sudjeluju pješaci često rezultiraju teškim ozljedama pješaka ili njihovom smrću. Kako bi se sigurnost pješaka poboljšala, brojni proizvođači automobila razvijaju sustave u automobilima čija je svrha usmjerena upravo prema izbjegavanju udara pješaka ili smanjenja posljedica udara. Cilj rada je ukazati koje će to specifične nove tehnologije i uređaji u automobilu u budućnosti imati učinak na opadanje smrtnosti pješaka u prometu.

\section{PJEŠAČKI PROMET}

Pješački promet predstavlja osnovni oblik kretanja s kojim svi drugi vidovi prometa počinju i završavaju. On je jedini način povezivanja sa svim dijelovima terena, odnosno grada, te je svima dostupan i koriste ga svi sudionici prometa. Prema statističkim podacima, kretanje pješaka sudjeluje s 20 do $30 \%$ u općem gradskom kretanju a manifestira se kao pravilno ili nepravilno kretanje (Barišić, 2014:181). Pravilno kretanje ostvaruje se prije svega zbog radnih, kulturno-životnih ciljeva

1 Bacc. ing. traff., studentica, Veleučilište u Rijeci, Vukovarska 58, 51000 Rijeka, Hrvatska.

E-mail: marina.balukcic.94@gmail.com

2 Dipl. ing. el., predavač, Veleučilište u Rijeci, Vukovarska 58, 51000 Rijeka, Hrvatska. E-mail: ivan.grakalic@veleri.hr

3 Datum primitka rada: 15. 1. 2017.; datum prihvaćanja rada: 20. 2. 2017. 
te se odvija na prometnicama koje vode do stanica javnog gradskog prometa, kolodvora, sportskih objekata, radnih mjesta, obrazovnih ustanova itd. Karakteristika nepravilnih kretanja je to što se najčešće odvijaju u trgovačkim, administrativnim i javnim centrima, koji su u pravilu dvosmjerni. Kod kretanja pješaka, za razliku od kretanja vozila, postoje određeni direktni utjecaji i specifičnosti odvijanja prometa, a neki od njih su:

- svrha kretanja determinira brzinu

- karakteristike sudionika u prometu

- promet se ne odvija „uređeno“, što značajno utječe na njegovu brzinu.

Rezultati ispitivanja provedeni u Švicarskoj kazuju kako prosječno svaki čovjek godišnje prijeđe oko 1.000 $\mathrm{km}$, te je za slobodno kretanje pješaka potrebno $1 \mathrm{~m}^{2}$ površine (Barišić, 2014:181). Po broju žrtava u prometnim nesrećama pješaci zauzimaju visoko drugo mjesto, što kazuje kako su nedovoljno zaštićeni u prometu te da su potrebne nove mjere zaštite. Posljedice prometnih nesreća u kojima su sudionici motorna vozila i pješaci nažălost su u većini slučajeva tragične za pješake ili su oni teško ozlijeđeni. Razlog tome je svima poznat, a govori o neusporedivo većoj masi vozila u odnosu na ljudsko tijelo. Razmjer poginulih pješaka u odnosu na broj prometnih nesreća je najveći.

Tablicom 1 koja sadř̌i sve četiri kategorije ugroženih sudionika u cestovnom prometu možemo prikazati usporedbu broja sudionika u prometnim nesrećama na prijeđeni kilometar na primjeru Republike Slovenije.

Tablica 1. Broj žrtava s obzirom na oblik putovanja

\begin{tabular}{|l|c|l|c|c|}
\hline & $\begin{array}{l}\text { Broj } \\
\text { žrtava }\end{array}$ & $\begin{array}{l}\text { Broj žrtava na } \\
100 \text { milijuna }\end{array}$ & & \\
\hline & & Putovanja & Kilometara & Sati \\
\hline Broj poginulih sudionika & & & & \\
\hline Vožnja biciklom & 227 & 12,5 & 4,6 & 64 \\
\hline Pješačenje & 1.753 & 7 & 6,6 & 27 \\
\hline Vožnja motorom & 670 & 122 & 11,4 & 342 \\
\hline Vožnja autom & 2.142 & 5,2 & 0,4 & 12,4 \\
\hline Vožnja autobusom & 17 & 0,4 & 0,006 & 1,4 \\
\hline Broj poginulih i teško ozlijeđenih sudionika & & & & \\
\hline Vožnja biciklom & 4.879 & 268 & 98 & 1.377 \\
\hline Pješačenje & 17.880 & 72 & 68 & 279 \\
\hline Vožnja motorom & 12.654 & 2.311 & 215 & 6.461 \\
\hline Vožnja autom & 29.346 & 71 & 5,7 & 170 \\
\hline Vožnja autobusom & 892 & 14 & 2 & 51 \\
\hline
\end{tabular}

Izvor: Topolšek (2002:512-516) 
Iz tablice 1 vidimo kako je broj mrtvih $\mathrm{i}$ teško ozlijeđenih s obzirom na prijeđenu udaljenost kod pješaka 12 puta veći nego kod putovanja osobnim automobilom. No ako se pogleda broj mrtvih i teško ozlijeđenih sudionika u prometu s gledišta utrošenog vremena za putovanje, onda se rizik pojedinih sudionika naglo promijeni. $U$ tom slučaju pješačenje ima više žrtava od putovanja osobnim automobilom samo 1,5 puta.

\section{SRAZ VOZILA I PJEŠAKA}

Krutost automobilske konstrukcije i velike razlike u masi pješaka i vozila nažalost ishode teškim ozljedama pješaka, a nerijetko i smrtnosti. Pri naletu vozila na pješaka, osim što se veći dio deformaciijske energije utrošen prilikom sudara prenese na tijelo pješaka, uključene su i ozlijede od padanja na tlo koje također pridonose ukupnom stupnju ozljeđivanja. Izuzevši krutost konstrukcije i masu automobila, važno je istaknuti kako različiti oblici i strukture kritičnog dijela vozila također imaju svoju ulogu u ozljeđivanju.

\section{1 Nalet vozila na pješaka}

Nalet vozila na pješaka takva je prometna nesreća u kojoj je pješak doživio tjelesne ozljede od vozila u pokretu (Rotim, Peran, 2011:101). Udar na pješaka može biti s bočne ili prednje strane ili nalet pješaka na bočnu stranu vozila. Prilikom ovakve prometne nesreće pješak može doživjeti ozljede od udara u dijelove vozila, odnosno od pada na kolnik. Najčešće je to kombinacija i vozila i kolnika (slika 1).

Slika 1. Varijante udara motornog vozila u tijelo pješaka

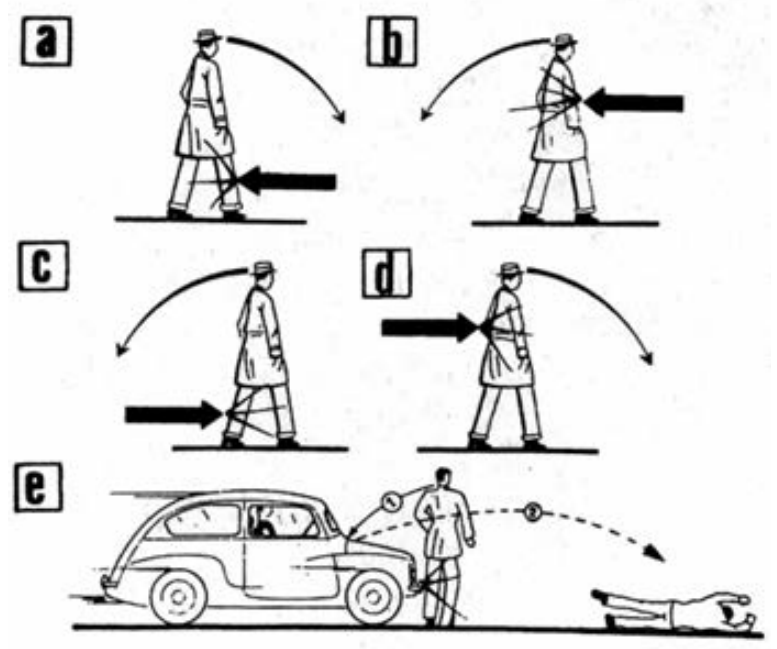

a. čelni udar vozila u nogu pješaka koja je oslonjena

b. čelni udar motornog vozila u središnji dio tijela pješaka

c. stražnji udar u oslonjenu nogu pješaka

d. stražnji udar u središnji dio tijela pješaka

e. faze pri naletu motornog vozila na bočnu stranu pješaka 


\section{2 Utjecaj oblika prednjeg dijela vozila na kinematiku pješaka}

Gibanje pješaka tijekom procesa naleta i odbačaja složena je pojava koja ovisi o brojnim faktorima:

- obliku profila prednjeg dijela vozila

- o dimenzijama vozila

- o težini vozila

- o veličini brzine kretanja vozila u trenutku naleta na pješaka

- o svojstvima čvrstoće strukture dijela vozila kojim je udaren pješak

- o položaju tijela pješaka u odnosu na širinu prednjeg dijela vozila

- o pravcu, smjeru i brzini kretanja pješaka u trenutku naleta

- o visini i težini pješaka

- o karakteristikama podloge na koju je odbačeno tijelo pješaka.

Ovi faktori od presudnog su značaja za sam ishod prometne nesreće jer definiraju položaj, veličinu i način djelovanja rezultirajuće udarne sile. Rezultirajuća udarna sila različito će djelovati na tijelo odrasle osobe i tijelo djeteta zbog razlike u visini položaja između težišta tijela odrasle osobe i djeteta. Položaj rezultirajuće sile također ovisi o obliku profila prednjeg dijela vozila. Tri osnovna oblika prikazana su sljedećom slikom (slika 2).

Slika 2. Utjecaj oblika prednjeg dijela vozila na kinematiku pješaka

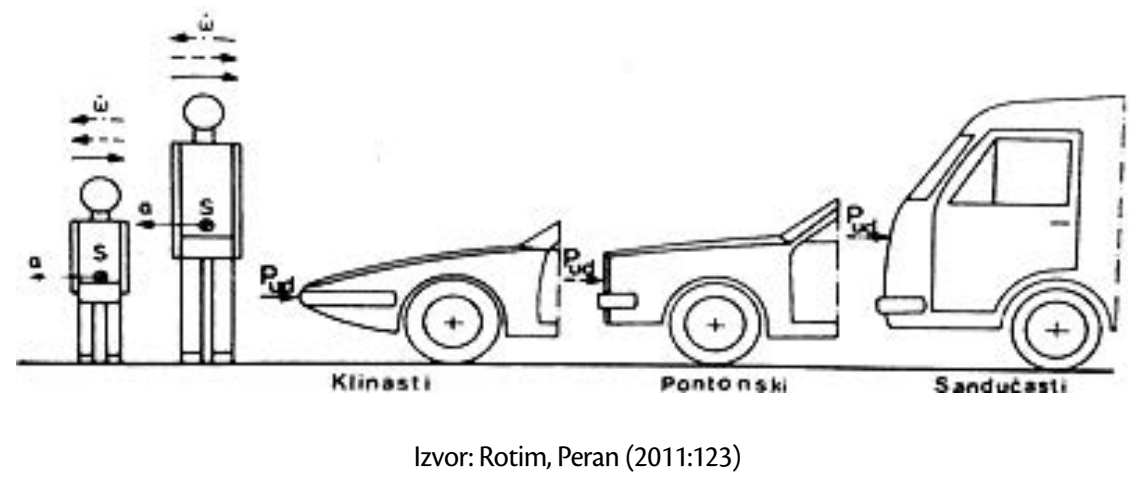

Ako dođe do naleta vozila klinastog ili pontonskog oblika (slika 2), zbog djelovanja sile ispod težǐšta čovjeka doći će do ubrzanja tijela pješaka te naposljetku do njegovoga nabacivanja na vozilo. No, ako se radi o djetetu pješaku, zbog svoga niskog težišta dijete će biti nabačeno na vozilo jedino ako se radi o vozilu klinastog oblika. Razlika u ishodu kod djece pješaka dogodit će se jedino ako je dijete više, tj. ako je viši položaj težišta njegova tijela. Tek tada može biti nabačeno i na vozilo pontonskog oblika.

Nalet na vozilo sandučastog oblika (slika 2) karakteristično je po tome što se bez obzira na starost pješaka oni nalaze $u$ istoj poziciji, odnosno pod istim uvjetima naleta. Jedina iznimka mogu biti djeca ako vozilo nije kočeno $u$ trenutku samog naleta, odnosno neposredno nakon njega. Tada postoji dodatna opasnost za djecu da ih vozilo naknadno pregazi. 
Oblik prednjeg dijela vozila izravno utječe na sam ishod prometne nesreće te moguće ozlijede koje se mogu pojaviti na tijelu čovjeka. Prema podacima iz prakse, a u kontekstu strukture ozljeda, $60 \%$ smrtnih posljedica uzrokovano je ozljedama glave i lica, dok 17,3\% smrtnih slučajeva uzrokuje kontakt sa samim poklopcem motora. Navedeni podaci ukazuju na potrebu da se pažljivo razmotri poklopac motora osobnog automobila u cilju osiguranja veće sigurnosti pješaka (Teng, Ngo 2010). Poklopac motora važan je za aerodinamiku i druge karakteristike vozila, a inicijalno modeliranje je, primjerice, pokazalo da poklopac koji manje ozljeđuje pješake ima lošiju (manju) torzijsku čvrstoću. Dodatnim ispitivanjima i modeliranjem dobivena je struktura poklopca motora koja je povoljnija za pješake koji će eventualno u nju udariti, bez smanjenja torzijske čvrstoće. Kao što znamo, proizvodnja realnih automobila daleko je od matematičkih modela, pa će proizvođači automobila osim ovakvih podataka morati još mnogo toga uzeti u obzir (Teng, Ngo, 2011).

Sukladno rečenom, svaki oblik prednjeg djela vozila detaljno se proučava prilikom ekspertiza prometnih nesreća te automobilska industrija na temelju zaključaka o tome čini modifikacije u cilju smanjenja težine ozljeda, a samim time i brojke smrtnosti pješaka. Potaknuti ovim činjenicama, iako je prvotni dizajn vozila prije svega u službi aerodinamike, sve veći broj automobilskih tvrtki nastoji osvojiti tržište upravo dizajnom automobila koji će prije svega biti u funkciji zaštite i sigurnosti vozača, ali i putnika i pješaka. Upravo prethodno navedeno rezultiralo je razvojem različitih testiranja oblika i međusobnih utjecaja čovjeka i vozila koji za cilj imaju implementiranje sustava čija će osnovna zadaća biti prije svega zaštita svih sudionika u prometnom procesu.

\subsection{Pješaci i Euro NCAP test}

Ispitivanja otpornosti vozila na sudare koja se vrše kod automobila koji su u fazi razvoja i plasiranja na tržište služe za spoznavanje optimalne zaštite putnika. Cilj ovakvih ispitivanja je istražiti kako poboljšati sigurnost putnika u vozilu smanjenjem sila koje nastaju prilikom sudara te tako smanjiti i opasnost ozljeđivanja sudionika u nesreći koji nisu u vozilu, a to je najčešće najugroženija skupina sudionika - pješaci.

Euro NCAP (engl. European New Car Assessment Programme) je Europski program procjene performansi sigurnosti vozila. Objavljuju izvješća o sigurnosti na nove automobile te ih ocjenjuju zvjezdicama. Svako pojedino vozilo ocjenjuje se kroz niz kriterija u crash-testovima. Kategorije koje se ocjenjuju jesu sigurnost vozača i putnika, sigurnost djece, sigurnost pješaka i sigurnosna pomoć. Jedna od bitnih stavki ovog testiranja je naglasiti kako se testira svaki dio automobila u ovisnosti s vanjskim utjecajem (prednji, bočni, stražnji, utjecaj s pješacima). Frontalno ispitivanje provodi se pri brzinama od $65 \mathrm{~km} / \mathrm{h}$ i to tako da se vozilo udara u čvrstu barijeru s $40 \%$ prednje površine na strani vozača. Bočni test provodi se pri brzinama od $50 \mathrm{~km} / \mathrm{h}$ tako da pokretna kolica udaraju u bočni dio automobila (vozačeva strana). Osim prvobitnih simulacija udara Euro NCAP danas sve više pažnje posvećuje i testovima ugroženosti pješaka u odnosu na pojedine dijelove automobila. Testovi pri brzinama od $40 \mathrm{~km} / \mathrm{h}$ izvode se za procjenu sigurnosti djece i pješaka te se pritom ocjenjuje mjesto udarca u noge i mjesto na kojem glava pješaka udara u vozilo (slika 3). 
Euro NCAP testiranja za pješake provodi uz pomoć specijalnih lutaka. Lutke su kopija ljudskog tijela te imaju vjerno kopirane fizičke karakteristike čovjeka. Lutka se sastoji od niza uređaja koji sakupljaju podatke. Svi vitalni dijelovi lutke opremaju se senzorima koji mjere ubrzanje i usporenje za vrijeme udarca te samu jačinu udarca na lutku, odnosno čovjeka.

Slika 3. Učestalost ozljeda na različitim dijelovima pješaka i dijelova vozila koja uzrokuju ozljede u prometnoj nesreći naleta pješaka na vozilo

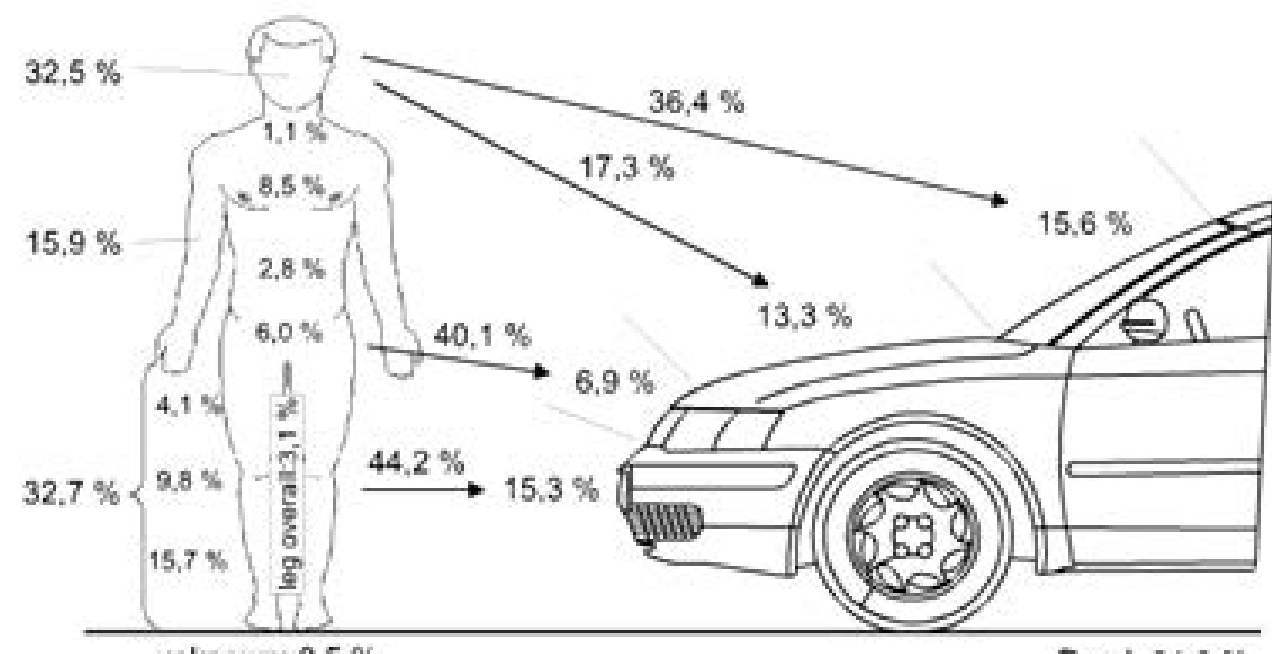

unknown: $0,5 \%$

Road: $31,9 \%$

Izvor: Kalliske, Friesen, Improvements to pedestrian protection as exemplified on a standard-sized car, Germany Report, No. 283

Slika 3 prikazuje međuovisnost čovjeka i vozila te postotke po pojedinim dijelovima ozljeđivanja pješaka i dijelova vozila koji najčešće uzrokuju te ozljede. Ovakvim testiranjem dolazi se do rezultata ugroženosti pješaka u odnosu na testirana vozila, čime Euro NCAP potvrđuje svoje sve strože kriterije te samim time potiče automobilsku industriju na proizvodnju sigurnijih automobila i u pogledu vozača i putnika i za zaštitu pješaka.

\subsection{Simuliranje rada aktivnih sustava pomoću crash-testova}

S obzirom na to da je prave testove sudara (engl. crash test), odnosno provjeru sigurnosti vozila novog modela moguće napraviti tek kada je vozilo gotovo, eventualne pogreške tada je vrlo teško ispraviti. To rezultira ogromnim troškovima te kašnjenjem u lansiranju modela. Dakako, ne smije se zaboraviti kako se sa svakim testom sudara vrijednost od najmanje 20.000 eura baci u vjetar (u ovom slučaju je to zid), a još najmanje toliko iznose troškovi samog testa i analize rezultata. Vođeni ovim činjenicama mnogi vodeći proizvođači u posljednje vrijeme intenzivno koriste virtualne testove sudara. Automobil je tada samo ideja na papiru, odnosno računalu, kako bi se predvidjelo njegovo ponašanje pri sudaru s drugim automobilom ili preprekom (slika 4). 
Slika 4. 3D simulacija frontalnog udara

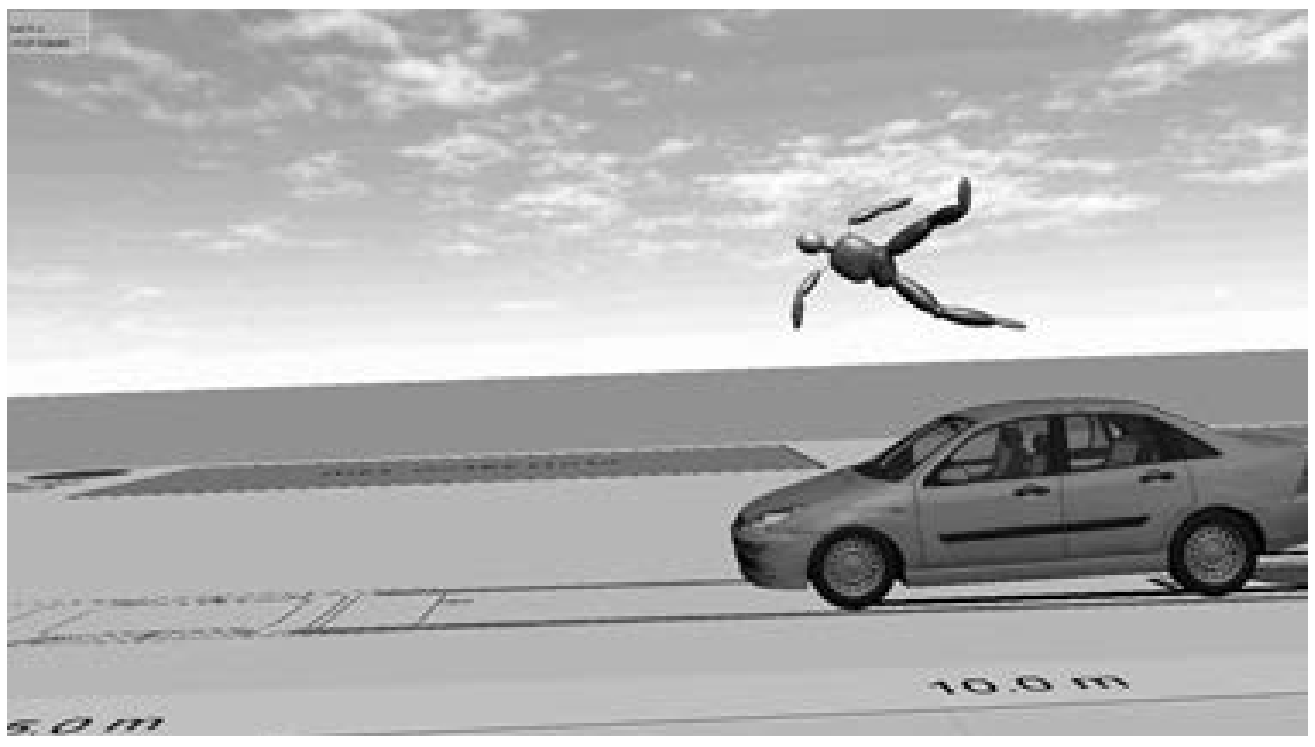

Izvor: https://i.ytimg.com/vi/XRv09kGRfAs/maxresdefault.jpg (21. 12. 2016.)

Služeći se ovakvim testiranjima moguće je modificirati početnu konstrukciju uz bitno manje troškove, odnosno unaprijediti je. Programi koji se koriste za simulacije imaju nevjerojatne mogućnosti te se automobili mogu promatrati odvojeno ili kao cjelina. Isto tako, lutke u stvarnim testovima sudara mogu registrirati ozljede na 20 mjesta, dok kompjutorska simulacija pruža neograničene mogućnosti, uključujući i variranje visine i mase putnika. Virtualni testovi sudara ne samo da štede veliku količinu novca, već omogućuju inženjerima da predvide ponašanje i najmanjeg dijela karoserije, motora, ovjesa i sl. i da eksperimentiranjem s više različitih koncepcija dođu do optimalnog rješenja. No, stvarni su testovi ipak nužni, zbog toga što se u simulaciji promatra idealizirani automobil, a nikad se ne može u potpunosti predvidjeti koliko će različitost u izradi utjecati na ponašanje u sudaru.

\section{SUSTAVI ZAŠTITE PJEŠAKA IMPLEMENTIRANI U MODERNIM VOZILIMA}

U nastavku ćemo opisati nekoliko modernih sustava kojima proizvođači vozila nastoje dati svoj doprinos smanjenju ugroženosti pješaka u cestovnom prometu. Kao što je ranije navedeno, veća sigurnost pješaka u prometu postiže se na dva načina - detekcijom pješaka i sprječavanjem naleta te ublažavanjem posljedica naleta ako do njega dođe. U tom smislu, sustave zaštite pješaka možemo, kao i ostale sustave sigurnosti u vozilima, podijeliti na aktivne i pasivne. Sustavi opisani u sekcijama 4.1. i 4.2. jesu aktivni sustavi, a oni pod 4.3., 4.4., i 4.5. su pasivni sustavi zaštite pješaka. 


\section{1 Sustav detekcije pješaka}

Sustav detekcije pješaka koji je razvila tvrtka Volvo koristi radar i kameru kako bi što učinkovitije identificirao pješake koji su u zoni naleta vozila (slika 5). Sustav djeluje u nekoliko etapa i razina, ovisno o udaljenosti pješaka i vozila. Kad sustav prepozna pješaka u zoni naleta, on najprije upozorava vozača zvučnim signalima i crvenim svjetlom na gornjem dijelu vjetrobranskog stakla. Ako vozač ne reagira na ta upozorenja, sustav aktivira kočnice automobila te usporava ili potpuno zaustavlja vozilo. Ovaj sustav detekcije pješaka može u potpunosti izbjeći udar pješaka pri brzinama manjim od $35 \mathrm{~km} / \mathrm{h}$, a pri brzinama do $80 \mathrm{~km} / \mathrm{h}$ smanjuje brzinu vozila prilikom udara, a samim time i posljedice nesreće. Sustav je tako podešen jer uvijek postoji opasnost od pogrešne detekcije pješaka, neželjenog i nepotrebnog snažnog automatskog kočenja koje može uzrokovati novi sudar, primjerice nalet vozila koje vozi iza vozila s ovakvim sustavom.

Slika 5. Princip rada kamere i radara u sustavu detekcije pješaka

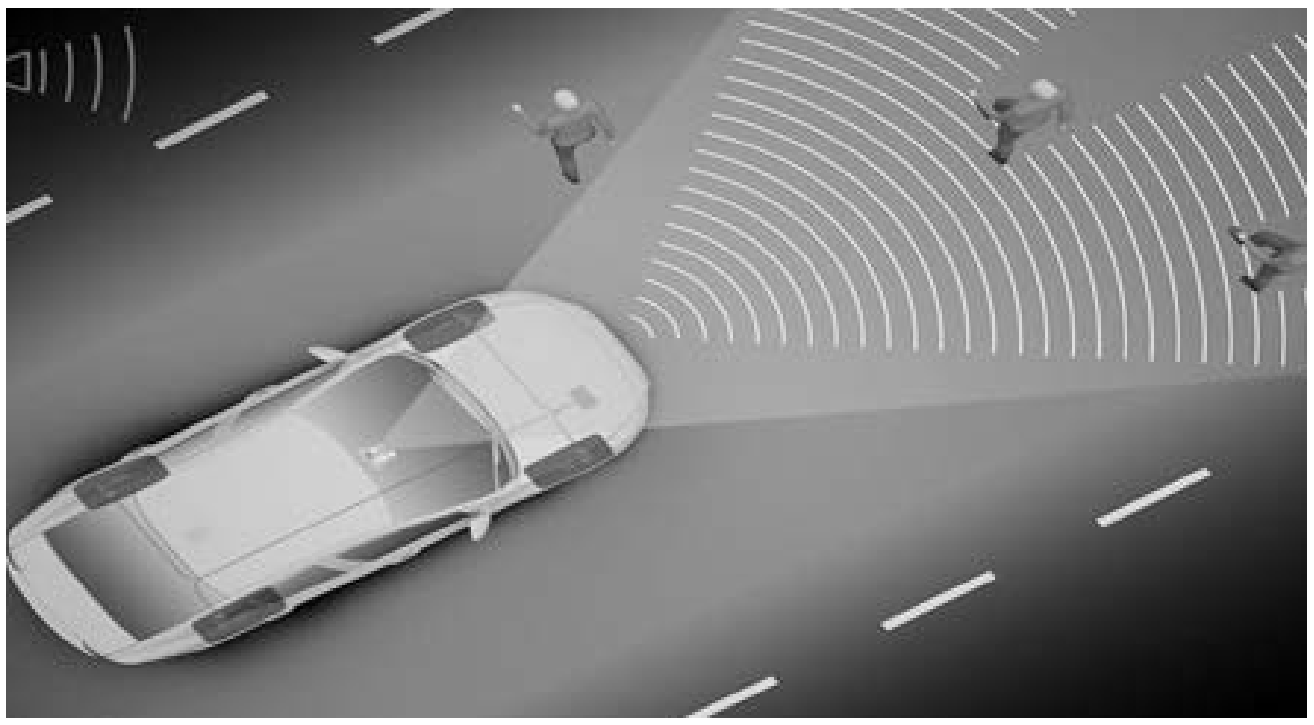

Izvor: http://www.volvocarslondon.co.uk/upload/thumbcache/0x0/images/media-library/72/5048c28ac2e6b.jpg (23. 12. 2016.)

Volvo procjenjujekako bi ovaj sustav, ako bi se ugrađivao kao dodatna oprema novim automobilima, mogao smanjiti postotak smrtnih stradanja pješaka uzrokovanih frontalnim sudarima za $24 \% \mathrm{u}$ odnosu na automobile koji nemaju taj sustav.

\section{2 Sustav poboljšane vidljivosti (engl. Night View)}

Sustav Night view (engl. nigt view - noćna vidljivost) posebno je dizajniran za rad u uvjetima slabe vidljivosti. Statistički podaci pokazuju kako se upravo većina prometnih nesreća događa u uvjetima slabe vidljivosti, kao što su noć, magla, kiša itd. Upravo u ovakvim uvjetima velika je razina opasnosti na cestama, jer lošu vidljivost često prati manjak koncentracije, a svjetlosni snop farova prestaje biti dovoljno učinkovit. 
Sustav Night view razvijen je prvenstveno za uvjete noćne vožnje, ali je pokazao dobru učinkovitost i u svim meteorološkim situacijama, te ga dijelimo na dva tipa koja se najčešće koriste, a to su:

- pojačivači svjetlosnog signala (aktivni),

- $\quad$ složeniji termički sustavi (pasivni).

Pojačivači svjetlosnog signala su aktivni sustavi koji rade na principu pomagala poput noćnih dalekozora, kamera te specijalnih noćnih naočala. Oni pojačavaju svjetlost internom optikom te sliku prostora ispred vozila, sada pojačane svjetline, reproduciraju na LCD-u u vozilu. Vozač na taj način na zaslonu vidi ono što svojim očima kroz vjetrobran ne vidi (dovoljno dobro). Prednost ovakvog sustava je svakako u činjenici da je dovoljna mala svjetlost kako bi se dobila korisna projekcija, ali problem je u tome što je ovaj sustav u potpunom mraku posve beskoristan, kao i u maglovitim uvjetima, jer ni uz odgovarajući izvor svjetla ne može otkriti što se skriva ispred vozila.

Za razliku od prethodno opisanih pojačivača svjetlosti sustavi termičke analize vidno učinkovitije funkcioniraju u uvjetima potpunog mraka. Rade na principu termalne kamere, odnosno detekcije infracrvene svjetlosti koju emitiraju svi objekti koji zrače toplinu. Cijeli sustav sastoji se iz optičkog dijela, toplinskog detektora, procesora i zaslona. Optički dio sustava prikuplja infracrvenu svjetlost do udaljenosti od oko 300 metara koju toplinski detektor analizira i obrađuje na način da detektira svjetlost određene valne duljine koja se zatim pretvara u sliku u specifičnom procesoru te se prikazuje na zaslonu (slika 6). Termičke kamere postavljaju se ispred hladnjaka te su od udaraca zaštićene rešetkama. Ovakav sustav radi i u potpunom mraku, no značajno je skuplji od prethodno opisanog.

Slika 6. Domet sustava Night view

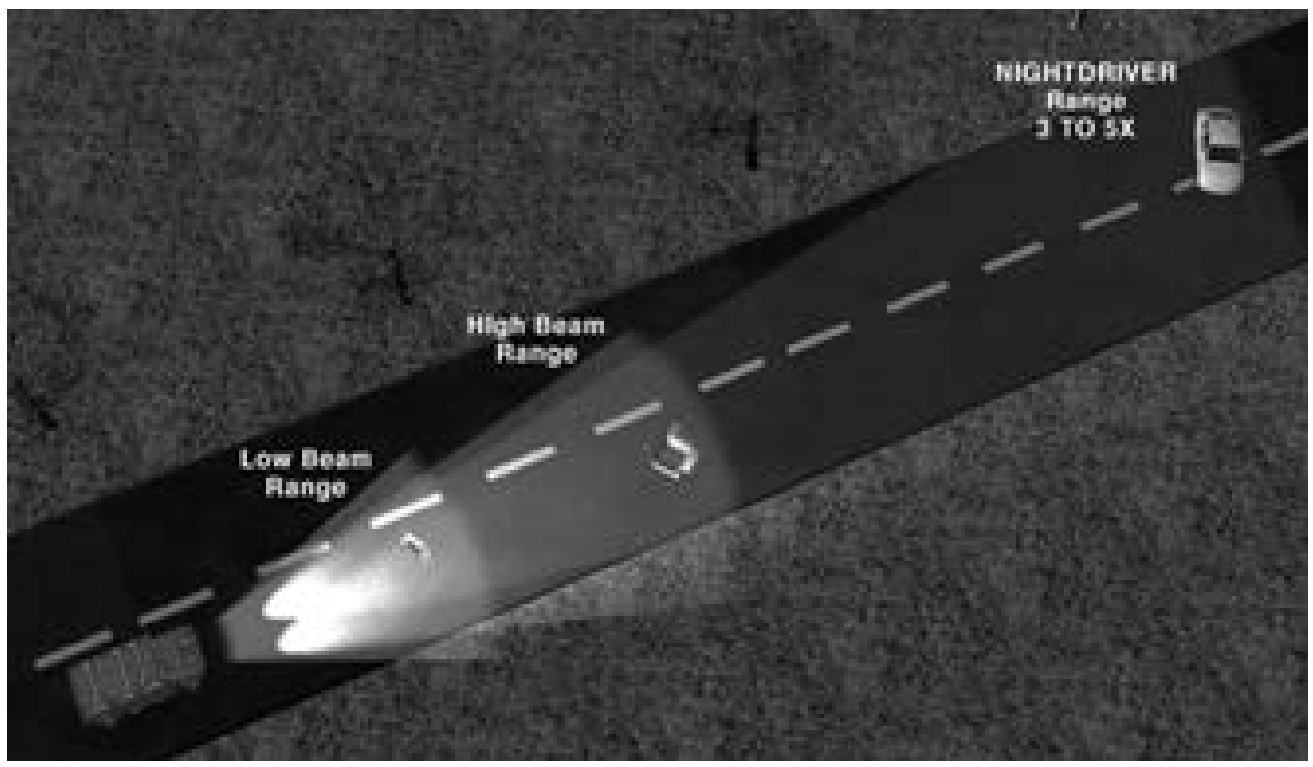

Izvor: http://arhiva.vidiauto.com/autotech/nightvision/ (23. 12. 2016.) 


\section{3 Zračni jastuci za pješake}

Glavni dio ovog sustava je zračni jastuk (vrlo sličan onima koje nalazimo unutar vozila) koji se aktivira u djeliću sekunde i otvara na području vjetrobranskog stakla automobila, pa pješak jednim dijelom tijela udara direktno u zračni jastuk (http://automobili.dnevnik.hr/novosti/clanak/ zracni-jastuci-za-pjesake-novi-sustav-volva (27. 12. 2016.)). Prilikom aktivacije sustava oslobađa se zadnji dio poklopca motora. Istovremeno se sustav zračnog jastuka počinje puniti plinom te napuhivanjem podiže poklopac motora za $10 \mathrm{~cm}$ (djelomično ga otvara ali tako da je prednji dio fiksan, a stražnji slobodan). Dobiveni razmak između tvrdih komponenti u motornom prostoru i poklopca motora stvara prostor za deformiranje poklopca motora, što rezultira stvaranje učinka amortiziranja, odnosno poklopac motora „prihvaća“ pješaka.

Slika 7. Dijelovi sustava zračnog jastuka za pješake

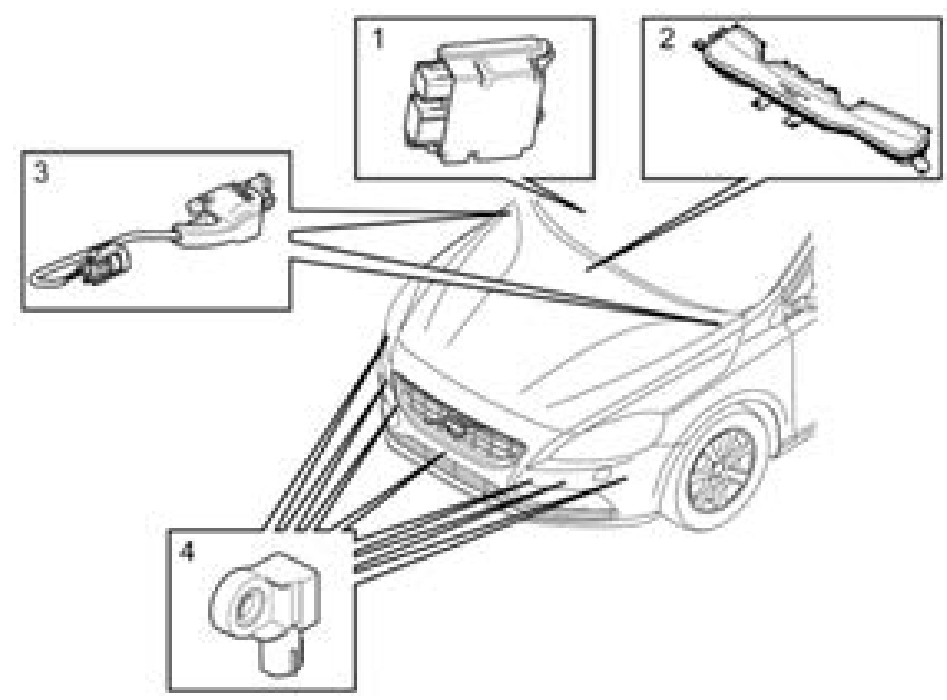

1. Modul zaštite pješaka

2. Zračni jastuk za pješake

3. Dva pogonska zgloba ispuštanja

4. Sedam pješačkih senzora

Izvor: http://moditech.com/de/pedestrian-protection-airbag (27. 12. 2016.)

\section{4 Aktivni poklopac motora}

Aktivni poklopac predstavlja sustav pasivne sigurnosti za zaštitu pješaka u slučaju frontalnog sudara. Ovaj pasivni sustav radi na principu automatskog djelomičnog podizanja poklopca u slučaju sudara s pješakom (slika 8). Sustav kontroliraju senzori na prednjem odbojniku i pirotehnički mehanizam. Poklopac se podiže $65 \mathrm{~mm} \mathrm{u} 40$ milisekundi i ostaje podignut bez obzira na jačinu udarca. 
Slika 8. Prikaz rada sustava aktivnog sustava poklopca u slučaju naleta na pješaka

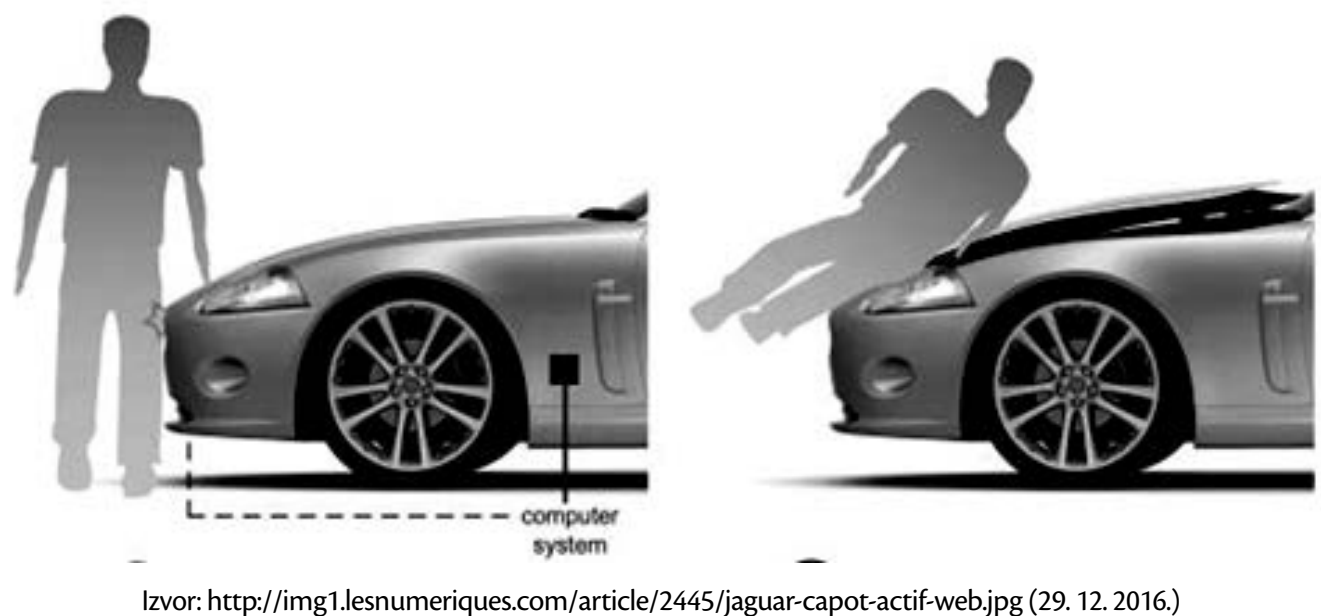

Rezultat ovakvog sustava je smanjen rizik od ozljeda prilikom udara. Pješak koji udari u poklopac neće doći u kontakt s tvrdim i tupim komponentama ispod poklopca. Poklopac je dizajniran da apsorbira energiju udarca te će samim time opasnost od ozljede biti smanjena, budući da glava i ramena pješaka ne dodiruju motor. Za ovaj sustav zaslužna je automobilska kompanija Citroen koja je upravo svojim modelom C6 predstavila inovativnu tehnologiju aktivnog poklopca. Ovim sustavom kompanija Citroen osigurala je najveći broj zvjezdica u kategoriji zaštite pješaka na Euro NCAP testiranju. Valja primijetiti da je ovaj sustav praktički sadržan u sustavu opisanom u poglavlju 4.3.

\subsection{Googleov patent lijepljenja pješaka na automobil}

Prethodno opisani sustavi (poglavlja 4.3 i 4.4) imaju zadaću smanjiti posljedice primarnog udara na pješaka, no valja razmisliti i o sekundarnom udaru - o tlo ili o drugo vozilo ili o pješaka. $U$ želji da smanje ozljede nastale od pada pješaka na kolnik nakon udara vozila $\mathrm{i}$ istovremeno smanje mogućnost leta pješaka na drugo vozilo, stručnjaci tvrtke Google došli su na ideju kako bi najprihvatljivije rješenje bilo zadržavanje pješaka na vozilu. Naime, radi se o inovaciji s ljepljivim premazom koji se nalazi na prednjem dijelu vozila koje je zaštićeno završnim slojem premaza koji se aktivira u slučaju naleta pješaka ili životinje. Ljepljivi premaz automobila kompanije Google radi na principu ljepljive trake koja se koristi za hvatanje muha. Ako dođe do naleta pješaka na automobil aktivira se ljepljivi premaz koji automatski zadržava pješaka na vozilu, odnosno nosi ga zalijepljenog dok se vozilo ne zaustavi (slika 9). Ovaj sustav svakako bi trebalo kombinirati sa sustavima opisanim u poglavljima 4.3 ili 4.4, no ovaj patent ne podrazumijeva takvu kombiniranu primjenu. Dizajniran je za samovozne automobile koje razvija tvrtka Google. Iz Googlea, međutim, objašnjavaju kako ovaj patent žele prilagoditi svakom automobilu. Valja primijetiti da je ovaj sustav (za razliku od prethodnih koji se već mogu kupiti) u vrlo ranoj konceptualnoj fazi te sa zanimanjem očekujemo kako će Google riješiti problem ljepila koje postaje ljepljivo u djeliću sekunde (onda 
kada je to potrebno) te prestaje biti ljepljivo kada ozlijeđenog pješaka treba odvojiti od poklopca motora i pružiti mu pomoć.

Slika 9. Prikaz ljepljive površine na prednjem dijelu automobila kompanije Google
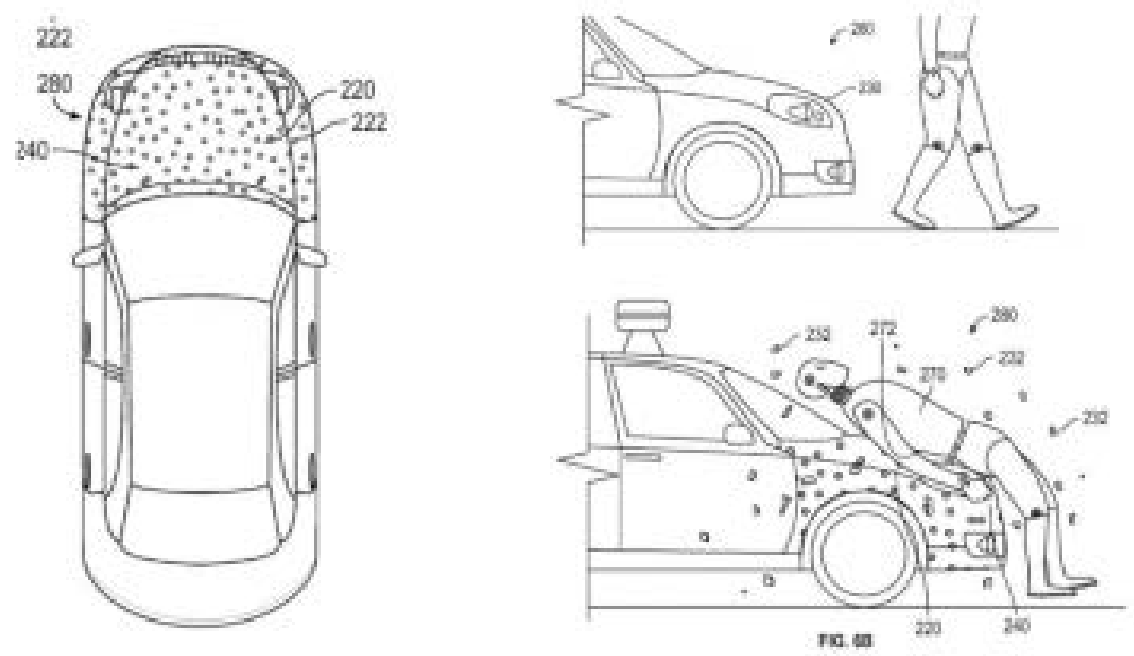

Izvor: http://roa.h-cdn.co/assets/16/20/980x490/landscape-1463664949-google-patent.jpg (5. 1. 2017.)

\section{ZAKLJUČAK}

Najugroženiji sudionici cestovnog prometa svakako su pješaci. Oni nemaju direktne vanjske zaštite, zbog čega su izloženi i zadobivanju teže ili lakše ozljede, nerijetko i sa smrtnim ishodima, osobito ako se dogodi nalet vozila na pješaka. Razlog navedenome neusporediva je razlika u masi pješaka i automobila. Pješak preuzima ukupnu silu koja ovisi o brzini i masi vozila i pješaka, a s obzirom na to da je prosječna masa automobila $1.500 \mathrm{~kg}$ i brzina kretanja vozila cestom preko $40 \mathrm{~km} / \mathrm{h}$, ova sila često uzrokuje teže ozljede ili smrt pješaka. Inovativne tehnologije predstavljaju sustave $u$ automobilima koji su opremljeni senzorima, kamerama, radarima, ne bi li prepoznali opasnost od naleta na pješaka. Ovakvi sustavi asistencija su vozaču te reagiraju u slučaju izostajanja pravovremene reakcije vozača, zbog koje se i događa veliki broj nesreća. $S$ druge strane, imamo i sustave koji osim djelovanja na kočni sustav reagiraju i poslije udara pješaka, a to su zračni jastuci i aktivni poklopac motora koji nastoje smanjiti fatalne ozljede naleta pješaka na vozilo. Svaki od navedenih sustava ima svoje jasno vidljive prednosti korištenja, no, s druge strane, niti jedan sustav, koliko god bio siguran, ne može zamijeniti kvalitetnog vozača. Zaključno navedenom, trebalo bi prije svega dobro informirati vozače o svim karakteristikama sustava te jasno naglasiti kako se vozač ne bi smio oslanjati na njih, već bi mu oni trebali biti samo dodatna pomoć u iznimnim situacijama. Nažalost, ovakvi sustavi još uvijek nisu isporučeni masovno u velikom broju vozila. Oni predstavljaju dodatnu opremu u automobilima višeg cjenovnog razreda, zbog čega se javlja i jedno od ključnih pitanja ovakvih tehnologija - koliko je vlasnik vozila spreman platiti i je li spreman platiti kako bi zaštitio pješaka? 


\section{LITERATURA}

Barišić, I. Sigurnost cestovnog prometa s ekspertizama prometnih nesreća, materijali s predavanja Barišić, I. (2014) Planiranje infrastrukture u cestovnom prometu, Rijeka: Veleučilište u Rijeci

Brozović, I. (2003) Pješački promet i planersko-projektni parametri pješačkih komunikacija i pješačkih prostora u gradovima, habilitacijski rad, Rijeka

Jović, M. (2016) „Više simulacije manje gužvanja lima“, Autorevija, br. 38.

Kalliske, I., Friesen, F. Improvements to pedestrian protection as exemplified on a standard-sized car, Germany Report, No. 283

Magdić, Z., Kovačević, V., Bokulić, D. (2013) „Prepoznavanje faktora rizika u cestovnom prometu“, Suvremeni promet, 33(3-4), p. 303-306.

Mikulić, D. (2011) Aktivni sustavi sigurnosti motornih vozila, Velika Gorica: Veleučilište Velika Gorica

Peran Z., Rotim F., Mihoci F. (2011) „Cestovnoprometna sigurnost i prevencija nesreća u Republici Hrvatskoj“, Suvremeni promet, 31(3-4), p. 311-318

Rotim, F., Peran, Z., Forenzika prometnih nesreća, Hrvatsko znanstveno društvo za promet, Zagreb, 2011.

T-L Teng., V-L Ngo. (2010) „Optimization of bonnet thickness with respect to pedestrian safety“, Automobile Engineering, 10. 6. 2010., 1513., Proc. IMechE Vol. 224 Part D: J.

T-L Teng., V-L Ngo. (2011) „Redesign of the vehicle bonnet structure for pedestrian safety“, Automobile Engineering, 26. 5. 2011., 71., Proc. IMechE Vol. 226 Part D: J.

Topolšek D. (2002) „Mobilnost i prometna sigurnost najugroženijih sudionika u cestovnom prometu“, Suvremeni promet, 22(6), p. 512-516

http://moditech.com/de/pedestrian-protection-airbag (20.12. 2016.)

http://www.sup.hr/index.php?option=com_content\&view=article\&id=537:pedestrian-and-cyclist-detectiondoprinos-volva-sigurnosti\&catid $=35$ :vozila\&ltemid $=55$ (22. 12. 2016.)

http://www.mobileye.com/technology/applications/pedestrian-detection/ (15. 12. 2016.)

http://www.iihs.org/iihs/sr/statusreport/article/46/3/2 (12. 12. 2016.)

http://automobili.dnevnik.hr/novosti/clanak/provjerite-sigurnost-automobila-euro-ncap-crash-test (13. 11. 2016.)

http://www.cqm.rs/2007/pdf/2/19.pdf (10. 12. 2016.)

http://www.magazinauto.com/koliko-su-automobili-zaista-bezbedni/ (14. 11. 2016.)

http://autostart.24sata.hr/vijesti/nova-tehnologija-detekcije-da-ne-zgazite-pjesake-174 (20. 12. 2016.)

http://sup.hr/index.php?option=com_content\&view=article\&id=707:volvom-protiv-nesrea-nova-spaplatforma-poveava-sigurnost\&catid $=40$ :novosti\&ltemid $=61$ (27. 12. 2016.)

http://www.dailymail.co.uk/news/article-3598049/Google-proposes-protective-coating-pedestrians-stuck-caraccident.html (16. 12. 2016.)

http://www.mycitroen.hr/tehnologije/\#/tehnologije/ (29. 12. 2016.)

http://www.ford-krainc.hr/cd/578/Ford-Mondeo-s-tehnologijom-detekcije-pjesaka---Ford-Krainc.wshtml (30. 12. 2016.) 


\title{
INNOVATIVE IN-CAR SYSTEMS IN SERVICE OF PEDESTRIAN SAFETY3
}

\begin{abstract}
Endangerment of pedestrians in traffic is manifested by the fact that they are second on the traffic accidents mortality scale. In an attempt to reduce the mortality rate of pedestrians, national authorities and the European commission have decided to intervene by introducing specific measures of protection and security in traffic. Those measures, besides infrastructure and the driver itself, include automotive industry and are expected to give significant contribution in reaching higher level of traffic security, including both car passengers and pedestrians. Car accident involving a pedestrian in the majority of cases results in a fatality. In the attempt to reduce the number of car accidents involving pedestrians, many automotive companies have started a development of the security systems which will allow drivers to react in due time and consequently reduce the severity of injury in pedestrians. Such systems can be active and passive and are described in this paper. Active systems involve some sort of spatial awareness technology (like radar) whose mission is to recognize the pedestrian standing or moving on the car's trajectory. Furthermore, such system is to alert the driver or take control of the vehicle and avoid the collision automatically. Passive systems tend to diminish the consequences of the primary and (or) secondary contact between the car and the pedestrian.
\end{abstract}

Key words:, pedestrian protection, security systems in the vehicle, traffic safety

Bacc. Ing. Traff., student, Polytechnic of Rijeka, Vukovarska 58, 51000 Rijeka, Croatia.

E-mail: marina.balukcic.94@gmail.com

2 M. Eng., Lecturer, Polytechnic of Rijeka, Vukovarska 58, 51000 Rijeka, Croatia. E-mail: ivan.grakalic@veleri.hr

3 Received: 15 January 2017; Accepted: 20 February 2017 